\title{
卵寄生蜂カメムシタマゴトビコバチの 夏ダイズ戋場における発生消長
}

\author{
水谷信夫 ${ }^{*}$. 広瀬義躬 ${ }^{* *}$. 樋口博也 ${ }^{*} \cdot$ 和田 節 ${ }^{*}$ \\ *九州農業試験場 \\ **九州大学農学部
}

\begin{abstract}
Seasonal Abundance of Oeencyrtus nezarae IsHII (Hymenoptera: Encyrtidae), an Egg Parasitoid of Phytophagous Bugs, in Summer Soybean Fields. Nobuo Mizurani (Kyushu National Agricultural Experiment Station, Nishigoshi, Kumamoto 861-11, Japan), Yoshimi HiRose (Institute of Biological Control, Faculty of Agriculture, Kyushu University, Fukuoka 812, Japan), Hiroya Hisccent and Takashi WadA (Kyushu National Agricultural Experiment Station, Nishigoshi, Kumamoto 861-11, Japan). Jpn. J. Appl. Entomol. Zool. 40: 199-204 (1996)

Seasonal fluctuations in the percentage parasitism of phytophagous bug eggs by Ooencyrtus nezarae IsHII and the adult abundance of this parasitoid were investigated in summer soybean fields of Kumamoto, Japan, in 1990 and 1991. O. nezarae parasitized the eggs of four phytophagous bugs, Riptortus clavatus

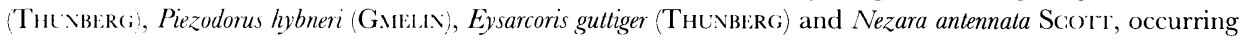
as a gregarious parasitoid only in eggs of $R$. clavatus. Among these hosts, $R$. clavatus eggs were the most important host resource for $O$. nezarae in summer soybean fields. Parasitism of $R$. clavatus eggs by $O$. nezarae was high in both years, and these host eggs had a high value as a resource due to their high density and gregarious parasitism. Only females of $O$. nezarae were caught by a sticky-suction trap before host oviposition and from the beginning of the host oviposition to the emergence of this parasitoid in soybean fields, indicating that only females colonize soybean fields. These colonizing females increased with increasing egg density of $R$. clavatus. The sex ratio of emerging $O$. nezarae adults became male-biased suggesting that females disperse more readily from emergence sites than males.
\end{abstract}

Key words: Ooencyrtus nezarae, egg parasitoid, Riptortus clavatus, phytophagous bugs, soybean pest

\section{緒}

\section{言}

\section{ダイズ加害性カメムシ類の個体数の制御要因として卵} 寄生蜂は重要な働きをしている(高須・㕕瀬, 1985 HIGilcHI, 1993; 樋[J, 1994)。中でも, カメムシタマゴ トビコバチ Ooencyrtus nezarae IsHII は寄主範囲が広く，夕゙ イズ加害性カメムシ類の有力な天敵とみなされている 高須・㕕瀬, 1985)

しかし，これらカメムシ類の多くは寄主範囲が㕕く (石倉ら，1955)，成虫の寄主植物に扔ける滞在時間が短 い(夏原, 1985：Hicic:HI, 1992)ことから, 寄主植物間 を頻繁に移動していると考えられる。このため, カメム シタマゴトビコバチの寄主資源は時間的・空間的に変化 すると予想され，春季クズ群落などダイズ國場以外の場 所で繁殖した成虫がダイズ戋場に飛来していると考えら れている(高須・公瀬；1986)。本寄生蜂の寄生活動につ
いては, 高須・広瀬 (1985) の報告以外にはなく, ダイズ 圃場への移出入に関する考察も高須・広瀬 $(1985,1986)$ 以外ほとんどなされていない。

そこで, 本稿では夏ダイズ戋場に扔ける本種の発生消 長と寄主カメムシの産卵消長について調査を行い，その 結果からカメムシタマゴトビコバチのダイズ圃場への移 出入について検討したので報告する。

本文に先立ち, 本稿の取りまとめに関しご校閲とご助 言をいただいた九州農業試験場の鈴木芳人博士に厚く御 礼申し上げる。

\section{材料および方法}

夏ダイズ戋場における食植性カメムシ類の産卵消長と カメムシタマゴトビコバチの各寄主に対する寄生率の消 長を調べるため, 1990 年と 1991 年の 2 年間, 熊本県 菊池郡西合志町の九州農業試験場内の夏ダイズ圃場 (品 
Table 1. Yearly abundance of phytophagous bug eggs and percentage parasitism by Ooencyrtus nezarae in summer soybean fields of Kumamoto in 1990 and 1991

\begin{tabular}{ccccrc}
\hline & \multicolumn{2}{c}{1990} & & \multicolumn{2}{c}{1991} \\
\cline { 2 - 3 } \cline { 5 - 6 } Bug species & $\begin{array}{c}\text { No. of eggs } \\
\text { collected }\end{array}$ & \% parasitism & & $\begin{array}{c}\text { No. of eggs } \\
\text { collected }\end{array}$ & \% parasitism \\
\hline Riptortus clavatus & 146 & 51.4 & & 123 & 41.5 \\
Piezodorus hybner & 1093 & 17.6 & & 623 & 9.3 \\
Eysarcoris guttiger & 220 & 32.3 & & 50 & 42.0 \\
Nezara antennata & 223 & 3.1 & & 0 & -- \\
\hline
\end{tabular}

種：コガネダイズ，1990 年は 2 a，1991 年は 4 a)に面 積 $1.4 \mathrm{a}$ の調査区を設定した。播種は 1990 年は 4 月 25 日，1991 年は 4 月 23 日に株間 $210 \mathrm{~cm}$, 畧間 $70 \mathrm{~cm}$ で 行い，播種後の圃場の管理は当地の慣行に従った。この 調査区内でダイズ株を 10 株に 1 株の割合でほほ均一に 選ぶ系統抽出で合計 100 株の固定調査株を設定した。こ れらの調査株について，1990 年は 6 月下旬，1991 年は 6 月上旬から，3 ないし 4 日おきに食植性カメムシ類 の卵を探索した。発見したカメムシ卵はその周辺に速乾 性インキで印を付け, 次回の調査目に回収した。カメム シ卵の探索・回収は調査株上で新たに産下された卵が発 見されなくなった時点 (8月末)で終了した。回収した卵 は室内に持ち帰り，試験管に入れて $25^{\circ} \mathrm{C}$ の条件下に保 存した。卵寄生蜂の羽化後, カメムシの種類ごとにカメ ムシタマゴトビコバチによる被寄生卵数を調べた。ま た, カメムシタマゴトビコバチ以外の卵寄生蜂が羽化し た場合は，その種名を記録した。カメムシも孵化せず， 卵寄生蜂も羽化しなかった寄主卵心解剖し, カメムシ夕 マゴトビコバチの寄生の有無を調へた。。本種の寄生が認 められた寄主卵を羽化の認められた卵と合わせて被寄生 卵とし，寄生率はこの被寄生卵数の回収卵数に対する百 分率として算出した。

また，固場内で繁殖した本種の羽化消長と性比を推定 するため，上記の被寄生卵から羽化したカメムシタマゴ トビコバチの雌雄の数を調べた。ここで，回収した卵が 本寄生蜂に寄生された日はその卵が発見された調査日で あると仮定し，ホソヘリカメムシ卵を寄主として用いた 場合の本寄生蜂の卵から成虫羽化までの有効積算温量 (189 日度) と発育零点 $\left(11.3^{\circ} \mathrm{C}\right)$ (NuMATA, 1993)，および 坂神・是永 (1981) の三角法によっで算出した野外の有効 積算温量から夏ダイズ國場における羽化日を推定した。

一方, 夏ダイズ圃場におけるカメムシタマゴトビコバ 千成虫の個体数の消長を調べるため，上記の調査区から 約 $8 \mathrm{~m}$ 離れた夏ダイズ國場の 1 か所に吸引粘着トラッ プ (東京エーエス社製) を設置し，1990 年は 6 月 8 日か
Table 2. Parasitoids emerging from phytophagous bug eggs collected in summer soybean ficlds of Kumamoto in 1990 and 1991

\begin{tabular}{|c|c|c|c|c|}
\hline \multirow{2}{*}{$\begin{array}{l}\text { Family and species } \\
\text { of egg parasitoids }\end{array}$} & \multicolumn{4}{|c|}{ Bug species ${ }^{1}$} \\
\hline & R.c. & P.h. & E.g. & N.a. \\
\hline \multicolumn{5}{|l|}{ Encyrtidae } \\
\hline Ooencyrtus nezarae IsHII & + & + & + & + \\
\hline Ooencyrtus acastus TRJAPITZIN & + & + & & \\
\hline \multicolumn{5}{|l|}{ Scelionidae } \\
\hline Gryon japonicum (AsHMEAD) & + & & & \\
\hline Gryon nigricorne (DoDD) & + & & & \\
\hline Telenomus triptus Nixon & & + & + & \\
\hline Trissolcus mitsukurii (AsHMEAD) & & & + & + \\
\hline
\end{tabular}

1) R.c.: Riptortus clavatus, P.h.: Piezodorus hybneri, E.g.: Eysarcoris guttiger, N.a.: Nezara antennata.

ら 8 月 16 日, 1991 年は 6 月 4 日から 9 月 27 日まで 捕獲された本寄生蜂の雌雄の数を毎日調査した。

結

果

\section{1. ダイズ圑場における年間のカメムシの産下卵数と カメムシタマゴトビコバチの寄生率}

今回の調査でダイズに産卵の認められた食植性カメム シはホソヘリカメムシ Riptortus clavatus (THUNBERG), イチ モンジカメムシ Piezodorus hybneri (GMELIN), マルシラホシ カメムシ Eysarcoris guttiger (THUNBERG), アオクサカメムシ Nezara antennata ScotT の 4 種であった (Table 1)。カメム シタマゴトビコバチはこれら 4 種のカメムシの卵すべて に寄生が認められ，1 卵ずつ産卵するホソヘリカメムシ の卵からは 1 卵当たり通常 4〜7頭の成虫が, 卵塊で産 卵される他の 3 種の寄主卵からは 1 卵当たり通常 1 頭, ごく稀に 2 頭の成虫が羽化した。

4 種のカメムシのうち，ホソヘリカメムシの産下卵数 は年次間で差が小さかった (Table 1)。これに対し，他の 3 種のカメムシでは年次間で差が大きく, 特にマルシラ ホシカメムシとアオクサカメムシの場合, その差が著し かった。また, これら 4 種の寄主卵に対するカメムシ夕 マゴトビコバチの寄生率は種によって著しく異なった。 

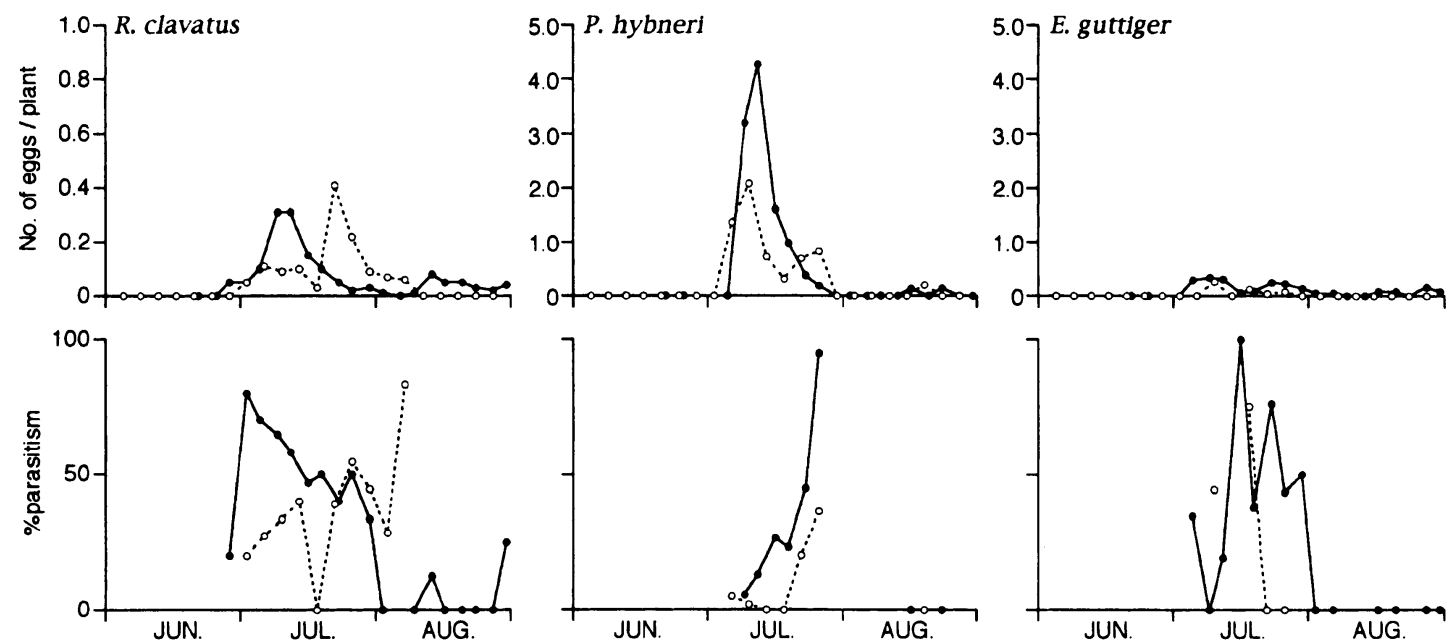

Fig. 1. Seasonal changes in number of eggs of Riptortus clavatus, Piezodorus hybneri and Eysarcoris guttiger and parasitism of these bugs by Ooencyrtus nezarae in summer soybean fields of Kumamoto in 1990 and 1991. Closed and open circles indicate the data in 1990 and 1991, respectively.

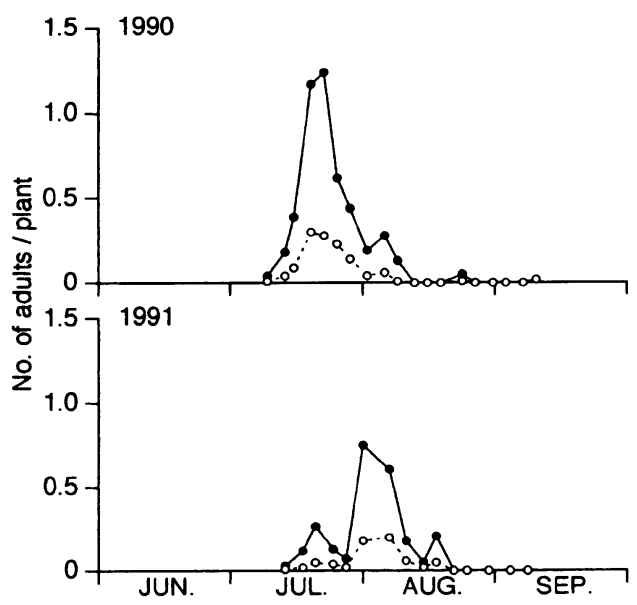

Fig. 2. Seasonal changes in number of newly-emerged adults of Oencyrtus nezarae in summer soybean fields of Kumamoto in 1990 and 1991. The number of adults was estimated from wasps emerging from the parasitized bug eggs collected in the field. Closed and open circles indicate female and male adults, respectively.

すなわち，ホソヘリカメムシ卵とマルシラホシカメムシ 卵に対する寄生率はいずれの年もそれぞれ $40 \%$ 以上お よび $30 \%$ 以上の安定した值を示したのに対し，イチモ ンジカメムシ卵とアオクサカメムシ卵に対する寄生率は いずれの年も低かった。

調査した 4 種のカメムシ卵にはカメムシタマゴトビコ バチ以外の寄生蜂が寄生した (Table 2)。このうち, イチ
モンジカメムシ卵では Telenomus triptus NixoN，また，ア オクサカメムシ卵ではミックリクロタマゴバチ Trissolcus mitsukurii (AsHMEAD) の寄生率が高く，それぞれの寄主の 優占種であった (水谷, 未発表)。なお, ミックリクロ夕 マゴバチの寄主としてマルシラホシカメムシを新たに記 録した。

2. 主要な寄主カメムシの産卵消長とカメムシタマゴ トビコバチの寄生率の消長

カメムシタマゴトビコバチによる寄生が認められた 4 種カメムシのうち, 本寄生蜂による寄生率の著しく低 かったアオクサカメムシを除く 3 種のカメムシの産卵消 長とこれらのカメムシ卵に対する本寄生蜂の寄生率の消 長を Fig. 1 に示した。ここで，ホソヘリカメムシ卵は1 卵から複数 (平均 5.4 頭/卵) のカメムシタマゴトビコバ チが羽化可能であるため，1 卯から1 頭の成虫が羽化す る他種カメムシ卵と寄主 1 卵当たりの資源としての価值 が異なる。そこで, Fig. 1 のカメムシタマゴトビコバチ の株当たり卵数の縦軸は寄主としての価值が他の寄主と 同一になるように表した。

3 種のカメムシはいずれもダイズの開花期から萊伸長 期にあたる 6 月末から 7 月初め頃より産卵が認められ た。その後, 1990 年のホソヘリカメムシとイチモンジ カメムシおよび 1991 年のイチモンジカメムシでは産下 卵数は急速に増加し，7月10日頃にピークに達した。 これに対し，1991 年のホソヘリカメムシは産下卵数の 上昇が遅れ，7月 20 日にピークに達した。いずれの年 

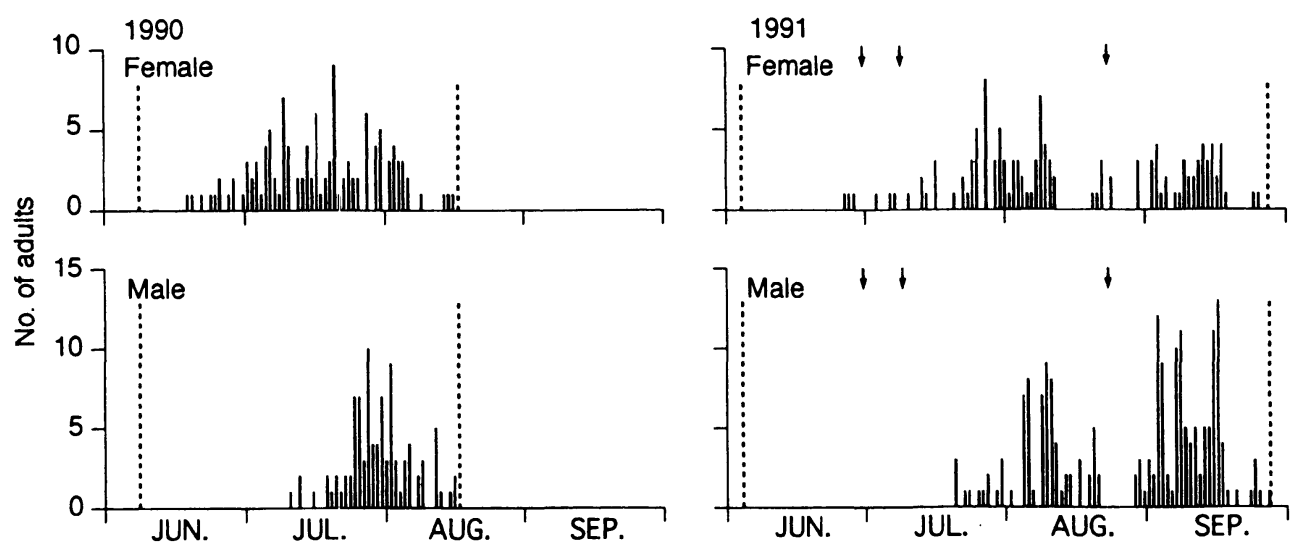

Fig. 3. Daily catches of Ooencyrtus nezarae adults in sticky-suction trap in summer sovbean ficlds of Kumamoto in 1990 and 1991 A trap was set during the period indicated by two dotted lines each year. Arrows indicate days when no trap was set.

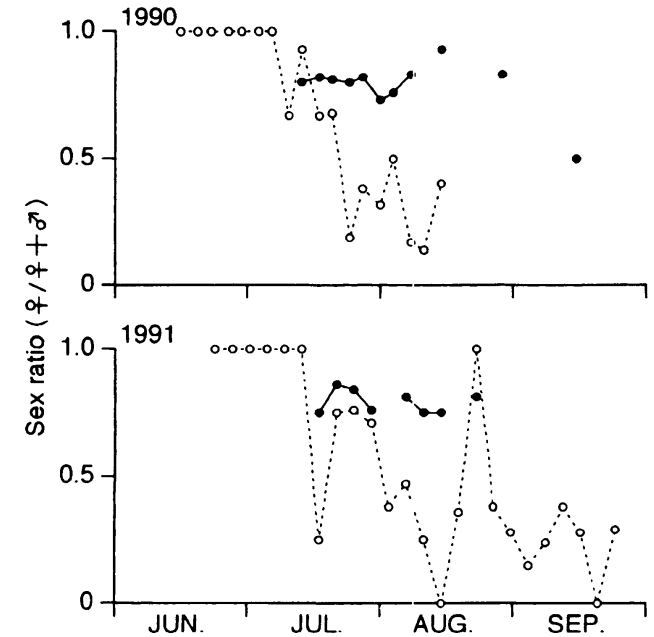

Fig. 4. Scasonal changes in sex ratios of Ooencyrtus nezarae adults caught in sticky-suction trep and of those emerging from parasitized hosts in summer soybean fields of Kumamoto in 1990 and 1991. Open and closed circles indicate the sex ratios of trapped adults and emerging adults, respectively.

もこれらのカメムシの産下卵数はピークに達した後徐々 に減少し，8月末にはほとんど産卵が認められなくなっ た。一方, マルシラホシカメムシの産下卵数は, カメム シタマゴトビコバチの寄主資源として他の 2 種カメムシ と比較した場合低い值で推移し，特に1991 年は上記 2 種に比べて著しく少なかった。

上記 3 種のカメムシの卵に対するカメムシタマゴトビ コバチの寄生はいずれの種でもカメムシの産卵直後から 認められたが(Fig. 1), その消長はカメムシの種で異なっ
ていた。イチモンジカメムシ卵でのカメムシタマゴトビ コバチの寄生率は，1990，1991 年ともに奇主密度の高 い7 月上旬から中旬には低く, その密度が減少する 7 月 下旬に高くなった。これに対し，ホソヘリカメムシ卵で は, 1990 年は 7 月上旬, 1991 年は 7 月下旬に卵密度 が最も高くなったが, カメムシタマゴトビコバチの寄生 率は 1990 年は 7 月上旬, 1991 年は 7 月下旬から 8 月 上旬にかけて高かった。一方, マルシラホシカメムシで の本寄生蜂の寄生率は卵密度に関わりなく時期によって 大きく変動した。

3. カメムシタマゴトビコバチの被寄生卵からの羽化 数と吸引粘着トラップによる捕獲数の消長

夏ダイズ围場に扔けるカメムシタマゴトビコバチの推 定羽化数の消長を Fig. 2 に示した。本寄生蜂の羽化は 1990 年は 7 月上旬, 1991 年は 7 月中旬から認められ, 1990 年は 7 月下旬, 1991 年は 8 月上旬に羽化数はピー クに達した。その後, 羽化数は減少し, 1990 年, 1991 年ともに8月下旬以降はほとんど羽化は認められなかっ た。

吸引粘着トラップによるカメムシタマゴトビコバチの 捕獲はカメムシの産卵が始まる少し前の 6 月中旬 (1990 年) あるいは6月下旬 (1991 年) から認められた (Fig. 3)。その後, 戋場で本寄生蜂の羽化が認められる 7 月上 旬まで捕獲された成虫は雌のみであった。この雌成虫の 消長は 1990 年と 1991 年で異なり, 1990 年は 7 月中 旬に, 1991 年は 7 月下旬に捕獲数がピークに達した。 一方, 雄成虫は圈場での本寄生蜂の羽化が始まる 7 月中 旬頃からトラップで捕獲され始め，7月から 8 月にかけ ての捕獲数の消長は被寄生卵からの推定羽化数の消長 
(Fig. 2)とほほ一致した。

トラップによる調査を 9 月下旬まで行った 1991 年に は，調査戋場で本種の羽化がほとんど認められない9月 に, 雌および雄成虫が多数捕獲され, 調査終了時まで捕 獲された(Fig. 3)。

4. カメムシタマゴトビコバチの被寄生卵からの羽化 個体およびトラップ捕獲個体の性比の季節的変動

カメムシタマゴトビコバチの被寄生卵からの羽化個体 およびトラップによる捕獲個体をカメムシ卵の回収調査 を行った 3 ないし 4 日ごとに合計し，その性比 (雌率) の継時的変化を Fig. 4 に示した。羽化個体の性比は 1990，1991 年の両年とも，調査期間を通してほほ 0.7 0.85 で，雌に偏った安定した值を示した。これに対し， トラップ捕獲個体の性比は, 捕獲開始直後には雌成虫の みが捕獲され，著しく雌に偏った值を示したが，調査戋 場で被寄生卵からの羽化が始まる 7 月中旬頃からその値 が徐々に低下し，羽化がピークに達する７月下旬ないし 8 月上旬以降は 1991 年の 8 月末を除き, 0 ～ 0.5 と羽化 個体の性比に比べ著しく雄に偏った值を示すようになっ た。この雄に偏った性比は, 調査終了時まで続いた。

\section{考察}

トラップによるカメムシタマゴトビコバチの捕獲個体 の性比は圃場で本種の羽化が始まる頃から雄に偏り，そ の後さらに雄に大きく偏った值を示した。この原因とし て雌成虫の粗場からの分散が考えられる。HiROSE et al (1996) も，ダイズ圃場においてカメムシタマゴトビコバ 于の羽化数が増加するにもかかわらず寄生率の上昇がみ られない原因として, 本種雌成虫のダイズ圃場からの分 散が寄主の存在下でも起こっている可能性を示唆してい る。本寄生蜂は産雄性単性生殖を行い (高須, 1989), そ の交尾は寄主卵あるいは寄主卵塊上で兄妹間で行われる (水谷, 未発表)。このような交尾様式を持つ種では, 雄 のパッチ間の移動は少ないとされている（HАMILT)， 1967)。同様に，多寄生性の寄生蜂や集合性の寄主を利 用する寄生蜂では交尾は羽化場所付近に限定され，雄 成虫は羽化場所付近にとどまることが多い (GODFRAY， 1994)。本種雄成虫の移動 ·分散も羽化場所付近に限定 されている可能性が高く，トラップで捕獲された個体の 性比が雄に大きく偏っていたことや，ダイズ圃場への飛 来・侵入時には雌成虫のみが捕獲されたことから，本種 では繁殖場所間の移動は雌成虫によって行われ，雌成虫 のみがダイズ圃場から分散すると推察される。

本寄生蜂は寄主範囲が広く (高須, 1989), 今回の調査
でも産卵の認められた 4 種のカメムシすべてに寄生が認 められた。しかし, 寄生率は寄主の種類によって大きく 異なった。ホソヘリカメムシ卵の場合, 寄生率はマルシ ラホシカメムシ卵とともに他の寄主卵に比べ高い値を示 した。ホソへリカメムシ卵は 1 卵から約 5 頭のカメム シタマゴトビコバチが羽化するため，1卵当たりの寄主 としての価值が他のカメムシ卵より高い。この寄主とし ての資源の量を考慮すると, ホソヘリカメムシ卵は本寄 生蜂にとって夏ダイズ圃場に多量に安定して存在する寄 主資源であった。また，その産下卵数の増加とともにト ラップによるカメムシタマゴトビコバチ雌成虫の捕獲数 も増加した。したがって，夏ダイズ圃場における本寄生 蜂の最も重要な寄主はホソヘリカメムシであると考えら れる。

圃場で本寄生蜂の羽化がほとんど認められない 9 月に トラップで多数の本種雌雄成虫が捕獲された。これらの 成虫が何に由来するものかは断定できないが，隣接した 秋ダイズ固場で本寄生蜂の羽化が認められた(水谷，末 発表)ことから，秋ダイズ圃場で繁殖した成虫が調査戋 場に侵入したと推察される。この時期に夏ダイズ圃場に はほとんど寄主卵が存在していないことから、これらの 成虫, 特に雌成虫が繁殖のために夏ダイズ固場に侵入し たとは考えにくく，秋ダイズ圃場からの移動・分散途中 の個体が捕獲されたものと考えられた。またここれらの 個体の性比が著しく雄に偏っていたことは，圃場で繁殖 し分散しなかった雄成虫に加え，隣接した秋ダイズ圈場 で羽化した雄成虫の一部が同圃場に侵入したためと推察 される。

\section{摘}

要

1990～1991 年の 2 年間，熊本県菊池郡の夏ダイズ圃 場で，ダイズ加害性カメムシ類の卵の回収を行い，カメ ムシ類の産卵数と卵寄生蜂の寄生率および羽化数の調査 を行った。また，吸引粘着トラップによるカメムシタマ ゴトビコバチの捕獲を行い, 本種の発生消長の調査を 行った。

1)ダイズ固場に産卵が認められた食植性カメムシは ホソヘリカメムシ, イチモンジカメムシ, マルシラホシ カメムシ，アオクサカメムシの 4 種であった。カメムシ タマゴトビコバチは 4 種のカメムシ卵すべてに寄生した が, 寄生率は寄主の種類によって異なり, ホソヘリカメ ムシ卵で両年とも高い值を示した。本寄生蜂はホソヘリ カメムシ卵にのみ多寄生で，1 卵当たりの寄主としての 価值を考慮するとホソヘリカメムシ卵は夏ダイズ圃場に 
多量に安定して存在する重要な寄主資源であった。

2) カメムシタマゴトビコバチは寄主カメムシの産卵 開始直前から圃場で捕獲され始め), ダイズ圃場への飛 来・侵入時には雌成虫のみが捕獲された。トラップによ るこの䧳成虫の捕獲数はホソヘリカメムシの産下卵数の 増加とともに増加した。圑場で本湩が羽化する時期での トラップによる捕獲個体の性比は圃場での羽化個体のそ れに比べて雄に大きく偏っており，雌成虫の分散性が雄 成虫より高いことが示唆された。

\section{引用 文 献}

Godfray, H.C.J. (1994) Parasitoids: Behrvioral and Evolutionary Ecology. Princeton, New Jersey: Princetcon University Press, 473 p. HaMil.Tox, W.D. (1967) Extraordinary sex ratios. Science 156 : 477-488.

HigicenI, H. (1992) Population prevalence of occurrence and spatial distribution pattern of Piezodorus hybneri adults (Heteroptera: Pentatomidae) on soybeans. Appl. Entomol. Zool. 27 : 363-369.

Higcc:HI, H. (1993) Seasonal prevalence of egg parasitoids attacking Piezodorus hybneri (Heteroptera: Pentatomidae) on soybeans. Appl. Entomol. Zool. 28 : 347-352.

樋口博也 (1994) ダイズ畑におけるイチモンジカメムシの産卵 特性と卵期の死亡要因. 応動昆 38: 17-21.

Hirose, Y., K. Takast and M. Takagi (1996) Egg parasitoids of phytophagous bugs in soybcan : Mobile natural encmies as naturally-occurring biological control agents of mobile pests. Biol. Control (in press)

石倉秀次・永岡 昇. 小林 尚. 田村市太郎 (1955) 大豆害虫 に関する研究 (第 3 報) カメムシ類によるダイズの被害, カメムシ類の生態及び防除法について。四国農試報 2: $147-195$.

夏原由博 (1985) ホソヘリカメムシの移動と産卵. 植物防疫 39 : $153-156$.

Nimata, H. (1993) Induction of adult diapause and of low and high reproductive states in a parasitoid wasp, Ooencyrtus nezarae, by photoperiod and temperature. Entomol. Exp. Appl. 66 : 127 134.

坂神泰輔 - 是永龍二(1981) 有効積算温度の簡易な新算出方法 “三角法”について，応動昆 $25: 52-54$.

高須啓志 (1989) カメムシタマゴトビコバチにおける既寄生 寄主の識別一その機構と適応的意義. 九州大学学位論文. $105 \mathrm{p}$.

高須啓志・広瀬義躬 (1985) 福岡市におけるダイズ加害性カメ ムシ類の卵寄生蜂の季節的寄生消長。九病虫研会報 31 : 127-131.

高須啓志・広瀬義躬 (1986) ダイズ加害性カメムシ類の卵寄生 蜂カメムシタマゴトビコバチの繁殖場所としてのクズ群 落. 応動昆 30 : $302-304$. 